\title{
Niobium carbide coatings produced on tool steels via thermo-reactive diffusion ${ }^{1}$
}

\author{
Recubrimientos de carburo de niobio producidos sobre aceros para \\ herramientas por medio de difusión termoreactiva ${ }^{2}$
}

Fredy Alejandro Orjuela Guerrero ${ }^{3}$

John Jairo Olaya Florez ${ }^{4}$

José Edgar Alfonso Orjuela ${ }^{5}$

\section{How to cite this article:}

F. A. Orjuela Guerrero, J. J. Olaya Flórez, J. E. Alfonso Orjuela, "Niobium carbide coatings produced on tool steels via thermoreactive diffusion," Ing. Univ., vol. 22, n0. 2, 2018. https://doi.org/10.11144/Javeriana.iyu22-2.ncpts

\footnotetext{
${ }^{1}$ Submitted on: May $19^{\text {th }}, 2017$. Accepted on: April $2^{\text {nd }}, 2018$. This article is derived from COLCIENCIAS-UNAL investigation project. ${ }^{2}$ Fecha de recepción: 19 de mayo de 2017. Fecha de aceptación: 2 de abril de 2018. Este artículo se deriva de un proyecto de investigación COLCIENCIAS-UNAL, Código de registro (1101-521-28337). Desarrollado por el grupo de investigación en análisis de falla e integridad de superficies (AFIS) de la Universidad Nacional de Colombia, Bogotá, Colombia.

${ }^{3}$ Ingeniero Mecánico, Universidad Nacional de Colombia. Maestría en Materiales y Procesos de Manufactura, Universidad Nacional de Colombia. Profesor Asistente, Departamento de Ingeniería Mecánica y Mecatrónica, Facultad de Ingeniería, Universidad Nacional de Colombia. Bogotá, Colombia. Correo electrónico: faorjuelag@unal.edu.co

${ }^{4}$ Ingeniero Metalúrgico, Universidad Libre de Colombia. Maestría en Materiales y Procesos de Manufactura, Universidad Nacional de Colombia. Doctor en Ingeniería, Universidad Nacional Autónoma de México. Profesor Titular, Departamento de Ingeniería Mecánica y Mecatrónica, Facultad de Ingeniería, Universidad Nacional de Colombia. Bogotá, Colombia. Correo electrónico: jjolayaf@unal.edu.co

${ }^{5}$ Físico, Universidad Nacional de Colombia. Magister en Ciencias, Universidad Nacional de Colombia. Doctor en Ciencia -Física, Universidad Autónoma de Madrid. Profesor Asociado, Departamento de Física, Universidad Nacional de Colombia, sede Bogotá, Correo electrónico: jealfonsoo@unal.edu.co
} 


\section{ABSTRACT}

Objective: In this work, niobium carbide $(\mathrm{NbC})$ coatings were deposited on substrates of the tool steels AISI H13 and AISI D2 using thermoreactive deposition/diffusion (TRD) in order to analyze their behavior against corrosion in a saline environment. Materials and methods: The niobium carbides were obtained using salt baths composed of borax pentahydrate, aluminum and ferroniobium. This mixture was heated at $1050{ }^{\circ} \mathrm{C}$ for 4 hours. The chemical composition was determined by X-ray fluorescence (XRF). The coatings were morphologically characterized using scanning electron microscopy (SEM), the crystal structure was analyzed using X-ray diffraction (XRD), and the electrochemical behavior was studied using potentiodynamic polarization curves and electrochemical impedance spectroscopy (EIS). Results and discussion: The XRF analysis indicated that the coatings contained $87.476 \mathrm{wt} \% \mathrm{Nb}$ and 51.943 wt\% $\mathrm{Nb}$ for the D2-substrate and the H13substrate, respectively. The SEM images revealed that the morphology of the surface of the coatings was homogeneous. The XRD analysis established that the coatings were polycrystalline, and the electrochemical tests established that the corrosion resistance increased slightly in the covered substrates with respect to the uncoated steels, with the best results being obtained in the layers of niobium carbide deposited on AISI D2 steel. Conclusions: The analysis of corrosion resistance revealed that the coatings prepared on D2 steel have a higher corrosion resistance because they have fewer surface imperfections, which causes the coating to exhibit a dielectric behavior.

Keywords: Coating; carbides; niobium; corrosion.

\section{RESUMEN}

Objetivo: En el presente trabajo se depositaron recubrimientos de carburo de niobio $(\mathrm{CNb})$ sobre aceros para herramientas AISI H13 y AISI D2 mediante deposición/difusión termoreactiva (TRD), con el fin de analizar su comportamiento frente a la corrosión en un ambiente salino. Materiales y métodos: Los carburos de niobio se obtuvieron empleando baños de sal, compuestos por borax pentahidratado, aluminio y ferroniobio; Esta mezcla se calentó a $1050^{\circ} \mathrm{C}$ durante 4 horas. La composición química de las capas obtenidas se determinó por fluorescencia de rayos X (FRX). Los recubrimientos se caracterizaron morfológicamente mediante microscopía electrónica de barrido (MEB), se analizó la estructura cristalina mediante difracción de rayos $\mathrm{X}$ (DRX) y se estudió el comportamiento electroquímico por medio de curvas de polarización potenciodinámica y espectroscopia de impedancia electroquímica. Resultados y discusión: El análisis FRX indicó que los recubrimientos contenían $87,476 \%$ en peso de $\mathrm{Nb}$ y $51,943 \%$ en peso de $\mathrm{Nb}$, para los sustratos $\mathrm{D} 2 \mathrm{y}$ H13 respectivamente. Las imágenes MEB revelaron que la morfología de la superficie de los recubrimientos era homogénea. El análisis DRX estableció que los recubrimientos eran policristalinos y las pruebas electroquímicas establecieron que la resistencia a la corrosión aumentaba ligeramente en los sustratos recubiertos respecto a los aceros sin recubrimiento, obteniendo los mejores resultados en las capas de carburo de niobio depositadas sobre acero AISI D2. Conclusiones: El análisis de la resistencia a la corrosión reveló que los recubrimientos preparados sobre el acero D2 tienen una mayor resistencia a la corrosión porque presentan menos imperfecciones en la superficie, lo que hace que el recubrimiento exhiba un comportamiento dieléctrico.

Palabras clave: Recubrimientos; carburos; niobio; corrosión. 


\section{Introduction}

To reduce the effect of corrosion and wear on equipment exposed to chemically aggressive environments and subject to wear, the industry applies protective coatings on these elements. These coatings are hard layers of carbides, nitrides, borides and oxides. These coatings are deposited using techniques such as physical vapor deposition (PVD) and chemical vapor deposition (CVD). In PVD, the sputtering technique is used, and in the CVD, spray pyrolysis and thermo-reactive deposition/diffusion (TRD) techniques are often applied [1].

The advantage of TRD is that the deposited layers of dense and continuous carbide can be applied to steels containing carbon percentages higher than $0.3 \%$ [1]. TRD is also used for coating surfaces with hard materials in fluidized beds, molten salt baths, or powder. In addition, TRD emerges as a simple and economical alternative for the production of layers of binary carbides such as $\mathrm{VC}, \mathrm{NbC}$, $\mathrm{TiC}$ or $\mathrm{Cr}_{7} \mathrm{C}_{3}$, which are formed by the reaction between the carbon atoms of the substrate and the atoms of the carbide-forming elements (CFE). These elements are dissolved in molten borax and are added in powder form, such as ferro-niobium, ferro-vanadium, ferro-tungsten, ferro-titanium, ferro-chrome and chrome [1], [2]. The use of carbide coatings on steels is due to their physical and chemical properties such as high surface hardness, excellent adhesion, and resistance to wear and corrosion [1]. Because the layer growth depends on the diffusion of carbon, the process requires relatively high temperatures ranging from 800 to $1250^{\circ} \mathrm{C}$ to maintain an adequate deposition rate. As shown in [3] and [4], the carbide coating thicknesses ranging from 4 to 15 microns are obtained in time periods between 10 minutes and 8 hours, depending on the bath temperature and the type of steel. $\mathrm{Nb}$ is an excellent $\mathrm{CFE}$ because it has a lower free energy of carbide formation and its free energy of formation of oxides is higher than that of $\mathrm{B}_{2} \mathrm{O}_{3}$ [5], [6].

Niobium carbide $(\mathrm{NbC})$ is a chemically stable compound with a cubic crystalline structure; it melts at a high temperature and has a high hardness. These properties make $\mathrm{NbC}$ potentially useful as a protective coating against corrosion. However, the characterization of the corrosion resistance of $\mathrm{NbC}$ has not been extensively explored. In particular, there are very few studies related to the corrosion resistance of the carbides obtained by TRD [7], [8]. The corrosion resistances of carbides, nitrides and borides produced using the PVD technique mainly have been studied. The wear resistance and hardness of layers containing carbides obtained by TRD have been analyzed [9][12], and those layers have been reported to have good tribological properties. X. S. Fan et al. [13], [14] recently studied the growth mechanism and microstructure of carbides prepared using TRD, analyzed the effect of the carbon activity in the growth of these coatings on AISI H13 and AISI 9Cr18 steel, and developed a mathematical model to explain this effect. The aim of the present work is to analyze the corrosion resistance of niobium carbide coatings grown on AISI D2 and AISI H13 steels using a TRD system with electrochemical techniques

\section{Experimental techniques}

\subsection{Preparation of the substrates}

$\mathrm{NbC}$ coatings were deposited onto substrates of AISI H13 and AISI D2 tool steel. These substrates were prepared with dimensions of $16 \mathrm{~mm}$ in diameter and $3 \mathrm{~mm}$ in thickness and were subsequently 
polished with 600 grit sandpaper and washed in an acetone solution for five minutes in an ultrasound device. The hardness values of the annealed AISI D2 and the annealed AISI H13 were $223 \mathrm{HB}$ and $200 \mathrm{HB}$, respectively. Table 1 lists the chemical composition of the substrates.

Table 1. Chemical composition (wt\%) of the steels and ferro-niobium used in the TRD process

\begin{tabular}{ccccccccccc}
\hline & $\mathrm{Nb}$ & $\mathrm{C}$ & $\mathrm{Si}$ & $\mathrm{Mn}$ & $\mathrm{Cr}$ & $\mathrm{V}$ & $\mathrm{Mo}$ & $\mathrm{P}$ & $\mathrm{Ni}$ & $\mathrm{Al}$ \\
\hline AISI H13 & & 0.9 & 1.10 & 0.40 & 5.25 & 0.95 & 1.35 & & 0.21 & \\
AISI D2 & & 1.47 & 0.36 & 0.55 & 11.96 & 0.84 & 0.70 & 0.02 & 0.27 & \\
Fe-Nb & 70 & 0.04 & 1.5 & 0.8 & & & & 0.04 & & 3.8 \\
\hline \multicolumn{8}{c}{ Source: Authors' own creation }
\end{tabular}

\subsection{Growth of the coatings}

The temperature conditions and TRD treatment time were $1050{ }^{\circ} \mathrm{C}$ and 4 hours, respectively. The reaction medium in the process is formed by $4 \mathrm{wt} \%$ aluminum and $20 \mathrm{wt} \%$ ferroniobium concentrations combined with a percentage of borax pentahydrate $\left(\mathrm{Na}_{2} \mathrm{~B}_{4} \mathrm{O}_{7} \cdot 5 \mathrm{H}_{2} \mathrm{O}\right)$ to complete the mixture. The samples were quenched in water without agitation. The time and temperature conditions ensured the complete austenitization of the steel used in this study without excessive distortion or abnormal grain growth. Samples of niobium carbide obtained on AISI D2 and AISI H13 steels will be called D2-NbC and $\mathrm{H} 13-\mathrm{NbC}$, respectively.

\subsection{Chemical and microstructural characterization}

The chemical composition of the layers was evaluated using a MagixPro Philips PW-2440 XRF spectrometer, equipped with a rhodium tube of $4 \mathrm{~kW}$ maximum power. This device has a sensitivity of $200 \mathrm{ppm}(0.02 \%)$ for heavy metals. Semi-quantitative analysis was performed using the IQ software. The specimens were ultrasonically washed in an acetone solution for 5 minutes before each measurement.

The microstructure of the coatings was determined with a PANalytical X'Pert PRO diffractometer using Bragg Brentano geometry with $\mathrm{Cu} \mathrm{K \alpha}$ radiation $\left(\lambda=1.5405 \AA\right.$ ) between $10^{\circ}$ and $60^{\circ}$ with steps of $0.02^{\circ}$, a current of $40 \mathrm{~mA}$ and a potential difference of $45 \mathrm{kV}$. The sweep range was $20^{\circ}$ to $90^{\circ}$. Analysis of the morphology and thickness of the coatings was performed using an FEI Quanta 200 electron microscope. The images were obtained using secondary and backscattered electrons accelerated at an energy of $20 \mathrm{kV}$. In the analysis of the cross section, transverse samples were cut. The samples were polished to a mirror finish and were attacked with Villela's solution to reveal their surface microstructure.

\subsection{Corrosion resistance analysis}

To analyze the behavior of the coated and uncoated substrates in the corrosion process, polarization Tafel tests and electrochemical impedance spectroscopy (EIS) were performed. The Tafel tests were performed in an AC Gill potentiostat manufactured by ACM Instruments, and the EIS tests were performed on a Gamry Instruments potentiostat-galvanostat reference mark 600. The two tests followed the procedures described in ASTM G5 and ASTM G52, respectively [12]. The 
experimental conditions for the development of the polarization Tafel analysis were as follows: a solution of deionized water to $3 \% \mathrm{NaCl}$ at room temperature; initial potential (Ei): $-0.3 \mathrm{~V}$; final potential (Ef): $0.5 \mathrm{~V}$; scan speed: $20(\mathrm{mV} / \mathrm{min})$; and $0.196 \mathrm{~cm}^{2}$ of exposed area of the sample in the solution. The EIS tests were performed in the same solution with the following conditions: initial frequency of $100 \mathrm{kHz}$; final frequency of $0.01 \mathrm{~Hz}$; and AC voltage of $10 \mathrm{mV}$.

The EIS measurements were conducted for 1, 24, 48, 72 and 168 hours. In all of the tests, the solution was stabilized for 45 minutes after the immersion of the sample in the electrochemical cell, which comprised a graphite counter electrode, a reference saturated calomel electrode (SCE) and a working electrode formed by the sample under test, all immersed in $250 \mathrm{ml}$ of solution. The Tafel polarization curves that were obtained were analyzed using Sequencer software version 5, and the graphs obtained by EIS were analyzed using the Gamry Echem Analyst software, modeled on an equivalent electrical circuit for a porous coating.

\section{Results and discussion}

\subsection{Chemical composition}

Table 2 presents the XRF results, which reveal the niobium percentages in the coatings. In the chemical analysis, trace amounts of sodium and aluminum were also observed and appear to be a residue from the borax, which is used as the reaction medium.

\begin{tabular}{|c|c|c|}
\hline ELEMENT & $\begin{array}{c}\mathrm{D} 2 \mathrm{NbC} \\
\text { (wt\%) }\end{array}$ & $\begin{array}{c}H 13 \mathrm{NbC} \\
(w t \%)\end{array}$ \\
\hline $\mathrm{Fe}$ & 9.654 & 38.477 \\
\hline $\mathrm{Nb}$ & 82.476 & 51.943 \\
\hline $\mathrm{V}$ & $*_{---}$ & 0.411 \\
\hline $\mathrm{Cr}$ & 1.237 & 1.744 \\
\hline $\mathrm{Na}$ & 2.923 & 2.590 \\
\hline $\mathrm{Al}$ & 0.87 & 0.576 \\
\hline Mo & 0.787 & 1.704 \\
\hline $\mathrm{Si}$ & 0.558 & 0.792 \\
\hline $\mathrm{Ca}$ & 0.237 & 0.251 \\
\hline $\mathrm{Mg}$ & 0.158 & *--- \\
\hline $\mathrm{K}$ & 0.291 & 0.414 \\
\hline $\mathrm{Cl}$ & 0.863 & 1.099 \\
\hline
\end{tabular}

\subsection{X-ray diffraction}

Figure 1 presents the X-ray diffraction (XRD) results of the niobium carbide coatings grown on AISI H13 and AISI D2 steels. The XRD analysis reveals that the niobium carbide was polycrystalline with a face-centered cubic (FCC) structure, of type $\mathrm{NaCl}$, in which the niobium atoms occupy the FCC phase lattice and the carbon atoms occupy the interstitial positions between the niobium atoms [15] (PDF card 00-010-0181) on both substrates. These results agree with those 
obtained by S. Sen and U. Sen (2008) [11]; Oliveira et al. (2006) [12]; Castillejo et al. (2013, 2011) [7], [16]; and Orjuela et al. (2014) [8]. Figure 1 also shows the planes belonging to the substrates.

Figure 1. X-ray diffraction pattern of $\mathrm{NbC}$ coatings grown on steel: a) AISI D2 and b) AISI HI3.

The XRD patterns of the substrates are included as references
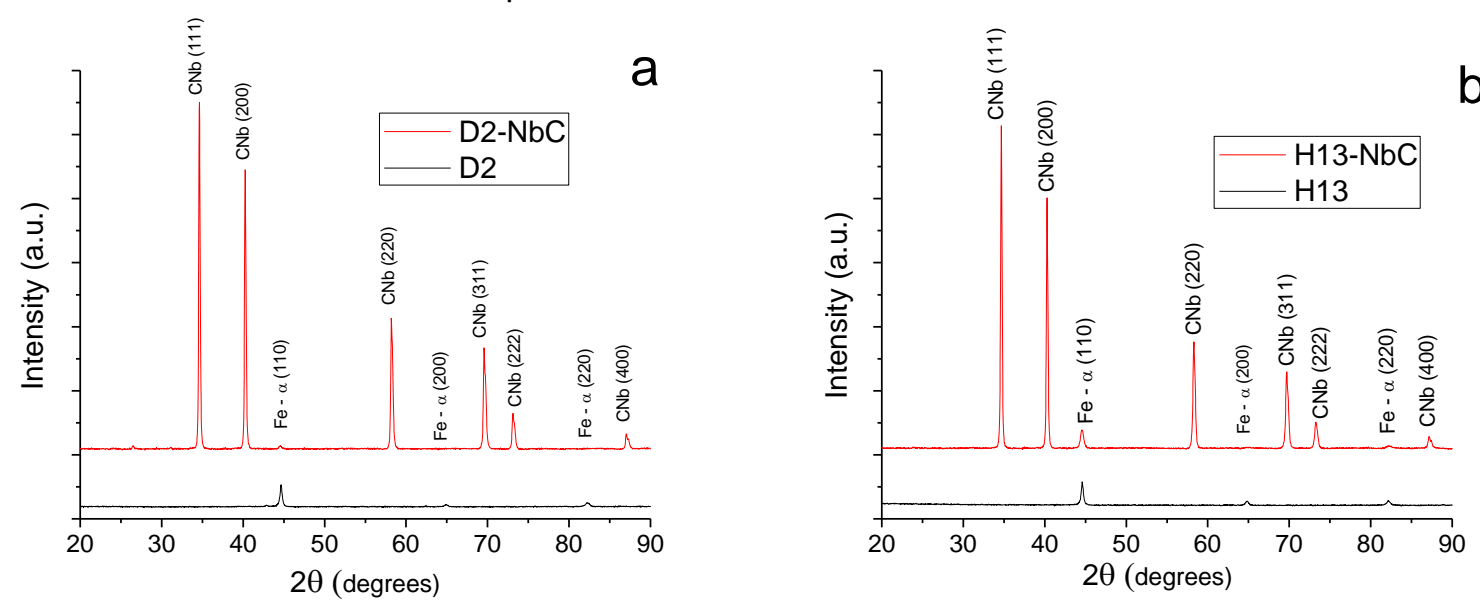

Source: Authors' own creation

\subsection{Morphology and thickness}

Figure 2 presents cross-sectional SEM images of the niobium carbide layers obtained on AISI D2 and AISI H13. In general, these coatings have a compact and homogeneous morphology and they show a high adherence to the substrate surface [7].

Figure 2. Transverse section SEM images of niobium carbide coatings deposited using TRD on a) AISI D2 and b) AISI H13.

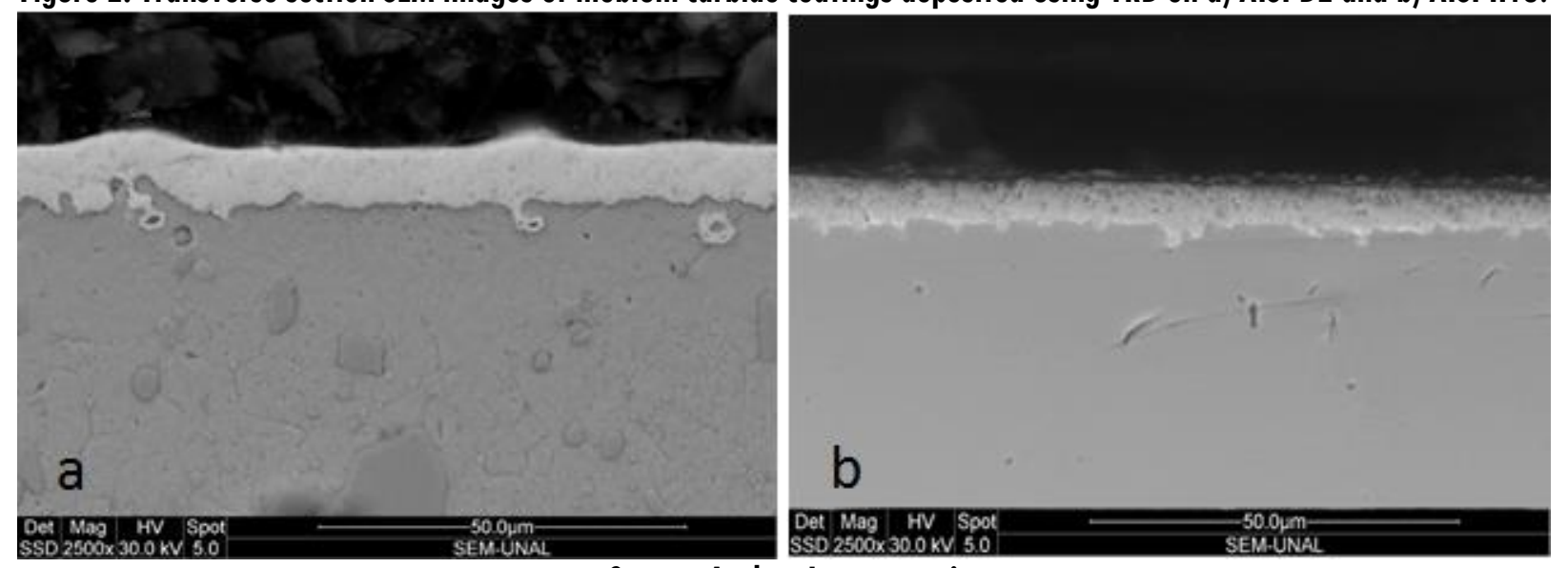

Source: Authors' own creation

The thicknesses obtained from the SEM micrographs were $13.0 \pm 0.6 \mu \mathrm{m}$ on AISI D2 and $9.5 \pm$ $0.5 \mu \mathrm{m}$ on AISI H13. The greater thickness of the layers obtained on AISI D2 is due to the growth coefficient $K_{0}$ of steel: 82 for D2 and 0.0345 for H13, according to the Arrhenius equation (see equation 1). 


$$
\frac{d^{2}}{t}=K=K_{0} e^{-\frac{Q}{R T}},
$$

where $\mathrm{d}$ is the layer thickness $(\mathrm{cm}), \mathrm{t}$ is time $(\mathrm{s}), \mathrm{Q}$ is the activation energy, $\mathrm{T}$ is the absolute temperature $(\mathrm{K}), \mathrm{R}$ is the gas constant $(8.314 \mathrm{~J} / \mathrm{mol} \mathrm{K}), \mathrm{K}$ is the growth rate $\left(\mathrm{cm}^{2} / \mathrm{s}\right)$, and $\mathrm{K}_{0}$ is a growth coefficient. The growth coefficient increases with the carbon content of the substrate [17], that is, with increasing carbon activity (Ac) in the substrate and the coating. The carbon activities in the D2 and H13 steels are approximately 0.33 and 0.11 , respectively, at $1000{ }^{\circ} \mathrm{C}$ [11], [12].

\subsection{Corrosion resistance}

Table 3 presents the average results of the corrosion potential and corrosion current density for the layers obtained for each of the steels with the corresponding standard deviation. Although the corrosion current density in the coated D2 steel substrate was similar to that obtained in the uncoated steel, the corrosion voltage was higher in the coated steel, thus showing an improvement in the electrochemical protection of the system. On the other hand, the coating of niobium carbide on $\mathrm{H} 13$ steel showed greater resistance to corrosion compared to uncoated steel. When comparing the coatings on the two steels, a greater corrosion resistance was observed in the coated D2 steel, since it presents a more positive value of the corrosion voltage compared to the coating on steel H13, which is most likely due to the percentage of porosity in the coatings [16]. In general, the niobium carbide coatings tend to improve the corrosion resistance of the substrate-coating system because the corrosion potential has a higher value compared with the uncoated steel; this effect is likely due to the formation of niobium oxide passivation layers on the coating surface [7], [8].

Table 3. Tafel polarization results of NbC coatings deposits on AISI D2 and AISI H13 steel

\begin{tabular}{ccccc}
\hline Sample & $\begin{array}{c}\text { Corrosion voltage } \\
(\mathrm{mV})\end{array}$ & $\begin{array}{c}\text { Standard } \\
\text { deviation }\end{array}$ & $\begin{array}{c}\text { Current density } \\
\left(\mathrm{mA} / \mathrm{cm}^{2}\right)\end{array}$ & $\begin{array}{c}\text { Standard } \\
\text { deviation }\end{array}$ \\
\hline D2 & -680.68 & 36.212 & $4.22 \mathrm{E}-05$ & $2.48 \mathrm{E}-06$ \\
D2-NbC & -512.27 & 45.673 & $4.16 \mathrm{E}-05$ & $1.86 \mathrm{E}-06$ \\
H13 & -791.45 & 31.761 & $7.08 \mathrm{E}-05$ & $4.33 \mathrm{E}-06$ \\
$\mathrm{H} 13-\mathrm{NbC}$ & -614.007 & 40.156 & $2.21 \mathrm{E}-05$ & $1.35 \mathrm{E}-06$ \\
\hline
\end{tabular}

Source: Authors' own creation

\subsubsection{Electrochemical impedance spectroscopy}

Figures 3 and 4, which were obtained using EIS, reveal that the niobium carbide coatings on both steels tend to increase the phase angle at low frequencies when the time of immersion in the electrolyte increases. In addition, these figures also reveal a shift of the peaks of the phase angle toward a lower frequency. This demonstrates that the coating enhances the corrosion resistance of the system due to the increased capacitive characteristics of the coating caused by the passivation process at low frequencies [18]-[20]. Therefore, the niobium carbide layer increased the ability to create a passivation layer, in this case, niobium oxide. These results differ from those obtained on uncoated steels at low frequencies because the phase angle tends to be $15^{\circ}$ on both substrates, and the impedance decreases to $10,000 \Omega$ (D2 steel) and 20,000 $\Omega$ (H13 steel) for an immersion time 
of $168 \mathrm{~h}$. These results suggest that the steels are attacked by the electrolyte, and therefore, the dissolution of corrosion products in the electrolyte increased with the time of exposure.

To model the electrochemical behavior of the coatings, we used an equivalent circuit (EC), which accounts for corrosion processes both in the coating-electrolyte system and the coating-substrate system and therefore uses constant phase elements (CPE) to simulate the phenomenon of corrosion in the two systems.

Figure 3. Bode diagrams of (a) uncoated AISI D2 and (b) AISI D2 coated with NbC
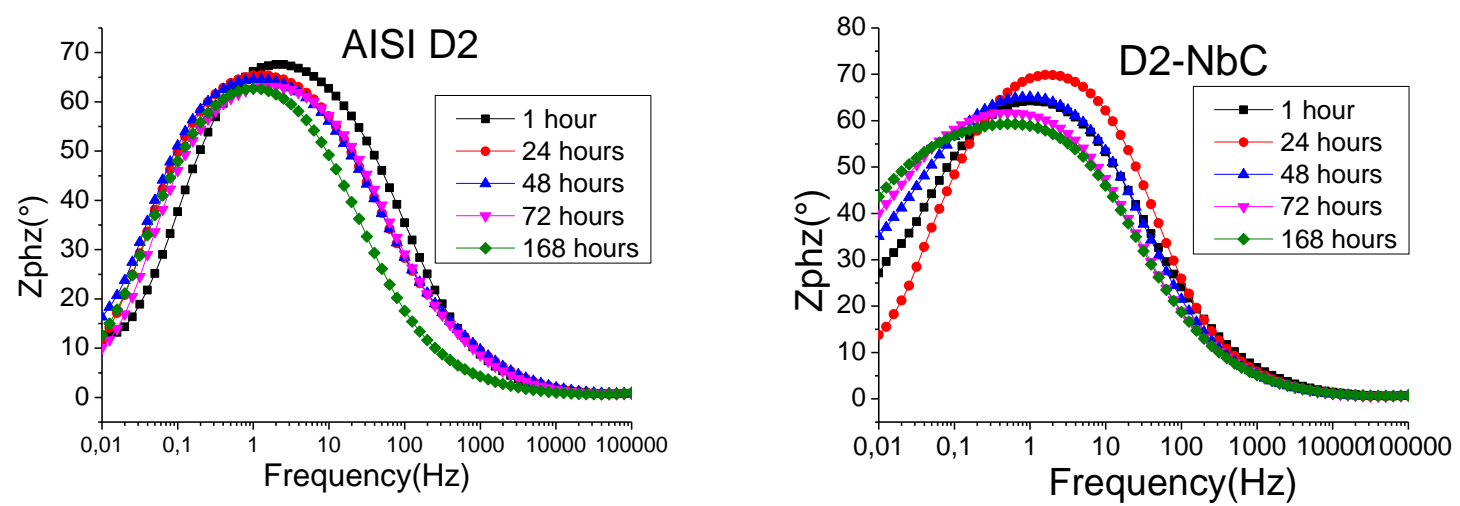

Source: Authors' own creation

Figure 4. Bode diagrams of (a) uncoated AISI H13 and (b) AISI H13 coated with NbC

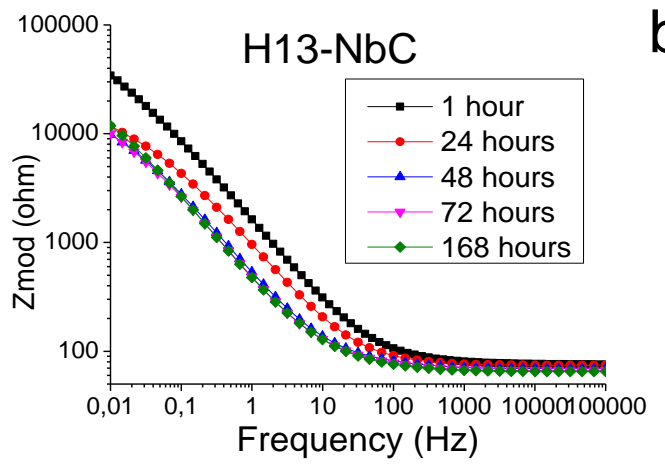

b

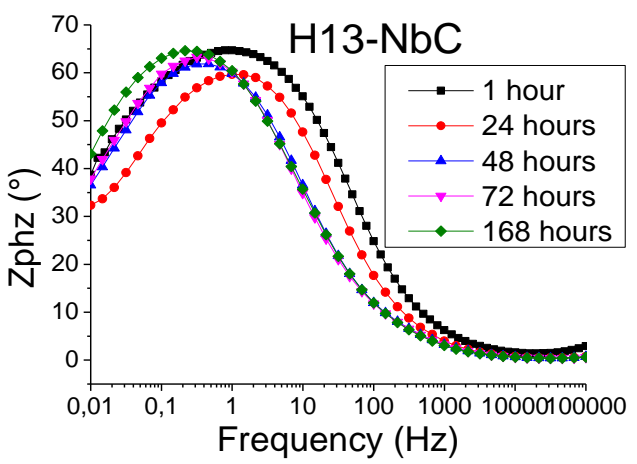

Source: Authors' own creation

In the coating-substrate system, the corrosion processes are galvanic and are produced due to the presence of defects such as pores and porous vacancies in the coating. Therefore, corrosion processes occur in the coating and at the coating-substrate interface through these defects. These results agree with those obtained by the authors in previous studies [8]. The electrochemical process that occurs in the interface can thus be simulated by the equivalent circuit illustrated in Figure 5 [8]. The circuit is formed by RC elements connected in series and in parallel; elements $\mathrm{R}_{\text {pore }}$ and CPE1 are equivalent to the coating that protects the metal [8], [21]. The resistor Rct and the capacitor CPE2 are equivalent to the dielectric double layer formed at the electrolyte-substrate interphase [22], [23]. The circuit is also formed by the resistor Rs, which is the resistance of the solution and reference electrode RE and the working electrode WE. The values obtained for each of these elements during the simulation are presented in Table 4. 
Figure 5. Equivalent circuit of $\mathrm{NbC}$ coatings deposited on $\mathrm{H} 13$ and $\mathrm{D} 2$ steels

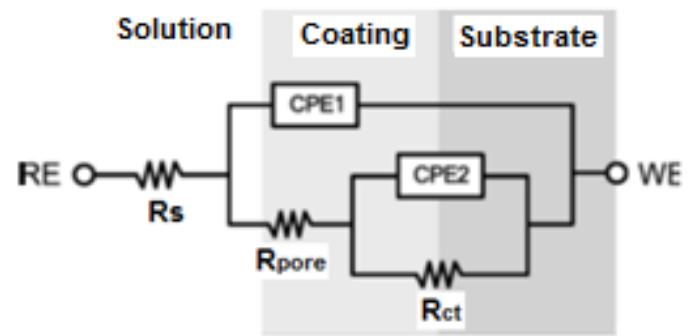

Source: Orjuela, (2014).

Table 4. Values of the elements that form the equivalent circuit

\begin{tabular}{|c|c|c|c|c|c|c|}
\hline & & $1 \mathrm{~h}$ & $24 \mathrm{~h}$ & $48 \mathrm{~h}$ & $72 \mathrm{~h}$ & $168 \mathrm{~h}$ \\
\hline \multirow{8}{*}{$\mathrm{H} 13-\mathrm{NbC}$} & $\operatorname{Rs}(\Omega)$ & 76.55 & 68.582 & 68.5 & 67.98 & 66.65 \\
\hline & Rpore ( $\Omega$ ) & 85.931 & 70.68 & 61.205 & 37.86 & 30.795 \\
\hline & $\operatorname{Rct}(\Omega)$ & 34694 & 29170 & 28860 & 28215 & 29790 \\
\hline & CPEI & $1.57 \mathrm{E}-04$ & $1.92 \mathrm{E}-09$ & $1.14 \mathrm{E}-12$ & $2.67 \mathrm{E}-12$ & $5.30 \mathrm{E}-04$ \\
\hline & $m$ & 0.7557 & 0.7805 & 0.74908 & 0.75328 & 0.757 \\
\hline & CPE2 & $1.85 \mathrm{E}-04$ & $2.86 \mathrm{E}-04$ & $4.92 \mathrm{E}-04$ & $5.33 \mathrm{E}-04$ & $1.11 \mathrm{E}-08$ \\
\hline & $n$ & 0.6471 & 0.7299 & 0.7462 & 0.7534 & 0.7552 \\
\hline & $R P(\Omega)$ & 34856.481 & 29309.262 & 28989.705 & 28320.84 & 29887.445 \\
\hline \multirow{8}{*}{$\mathrm{D} 2-\mathrm{NbC}$} & $R s(\Omega)$ & 120,4 & 109 & 99.48 & 101.60 & 96.62 \\
\hline & Rpore $(\mathbf{\Omega})$ & 5994.4 & 3480.3 & 4538.3 & 4945.2 & 4931.8 \\
\hline & $R c t(\Omega)$ & 41988 & 45876 & 53700 & 53437 & 59510 \\
\hline & $C P E 1$ & $3.88 \mathrm{E}-05$ & $6.97 \mathrm{E}-05$ & $1.66 \mathrm{E}-05$ & $1.94 \mathrm{E}-04$ & $2.29 \mathrm{E}-04$ \\
\hline & $m$ & 0.7598 & 0.8352 & 0.71312 & 0.73085 & 0.7098 \\
\hline & CPE2 & $5.15 \mathrm{E}-05$ & $3.55 \mathrm{E}-01$ & $1.28 \mathrm{E}-04$ & $1.78 \mathrm{E}-02$ & $6.14 \mathrm{E}-04$ \\
\hline & $n$ & 0.637 & 0.5918 & 0.7764 & 0.737 & 0.8143 \\
\hline & $R P(\Omega)$ & 48102.4 & 49465.63 & 58337.48 & 58483.6 & 64537.62 \\
\hline
\end{tabular}

Source: Authors' own creation

The results indicate that the solution resistance (Rs) of the niobium carbide coatings deposited on $\mathrm{H} 13$ steel tends to decrease as a function of immersion time, which is due to an increase in corrosion products. This increase means that there is a chemical reaction between the coating and the electrolyte, i.e., the coating loses its corrosion protective characteristic. In D2 steel, the Rs value is higher because the surface of the coating is less porous [7], [23], as evidenced by the Rpore values for each coating. The charge transfer resistance (RTC) between the electrolyte and the substrate has the highest value and increases with immersion time (in D2 steel), which implies that the double dielectric layer formed between the electrolyte and substrate appears to be the principal cause of the increased corrosion resistance of the coatings deposited on the substrates. The RTC values of the coating deposited on H13 steel are smaller than those deposited on D5 steel and do not change with time during the EIS test. These charge transfer resistance values are explained due to the properties of the ceramic coating and the large amount of chromium in D2 and H13 steels. Due to a diffusion process that is produced in treating TRD, chromium can be precipitated onto the surface and form a passive oxide layer.

The adjustment parameters $m$ and $n$ correspond to the constant phase elements CPE1 and CPE2, respectively. An ideal capacitor has $m$ and $n$ values of 1, and a leaky capacitor, pores or defects 
when its value ranges are represented by values between 0.5 and 1 [24]. The values of $m$ and $n$ obtained can determine whether the coatings tend to behave like a leaky capacitor, pores or defects because its value varies between 0.59 and 0.84, as shown in [21], [23] and [25], denoting a high roughness of both the interface between the coating and the substrate [25], [26].

Figure 6 presents the polarization resistance results $(\mathrm{Rp}=\mathrm{Rs}+\mathrm{Rpore}+\mathrm{Rtc})$ for the coatings deposited on the two steels studied; the Rp of the uncoated substrates is shown for reference. These results establish that the niobium carbide coatings deposited on AISI D2 steel improved the polarization resistance by a factor of four after 168 hours of immersion in the electrolyte.

Figure 6. Polarization resistance (Rp) results obtained for the equivalent circuit

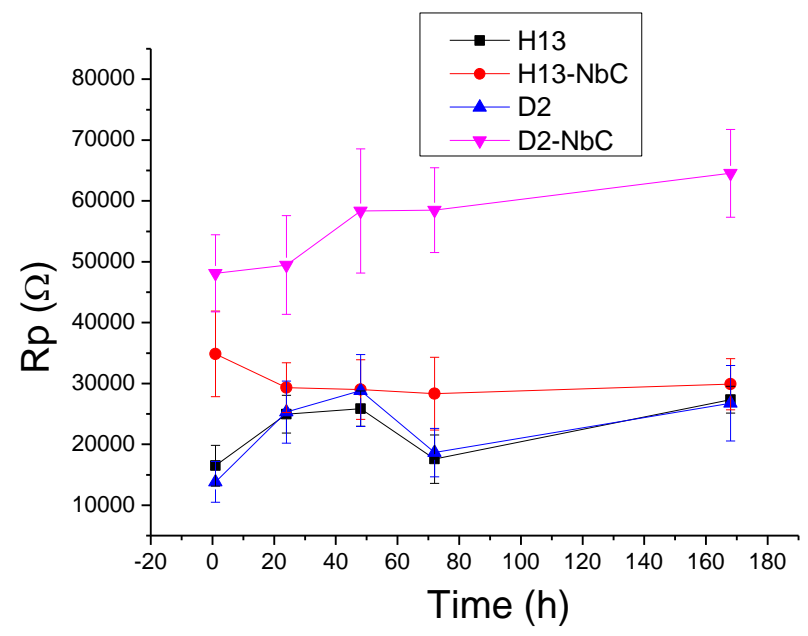

Source: Authors' own creation

\section{Conclusions}

In this work, niobium carbide coatings were prepared on AISI D2 and AISI H13 substrates using a deposition-diffusion thermoreactive technique. A greater thickness in the coatings deposited on the D2 steel was observed due to this substrate having higher carbon activity and growth coefficient values compared with those of the H13 steel.

The analysis of corrosion resistance using the EIS technique revealed that the coatings prepared on the D2 steel have a higher corrosion resistance because they most likely have fewer pores and imperfections on the surface, which causes the coating to exhibit dielectric behavior. Furthermore, the carbon activity and the amount of chromium present on the substrate appear to produce chromium oxides, which act as passivation films at the substrate-coating interface.

Finally, it was established that the niobium carbide coatings deposited on the AISI D2 steel have a polarization resistance that is four times larger than that of uncoated steel, thus establishing the anticorrosive effect exhibited by the coating. 


\section{Acknowledgments}

The authors wish to thank COLCIENCIAS, which supported the completion of this work through project RC338-2011. We also want to especially thank engineers Dagoberto Ramirez and Giovanni Cardona for their scientific and technical input.

\section{References}

[1] T. Arai, and S. Harper, Thermoreactive Deposition/Diffusion Process for Surface Hardening of Steels. [Online] Available: http://www.tool-dynamics.com/literature/papers/004.php

[2] T. Arai, and N. Komatsu, "Carbide Coating Process by Use of Salt Bath and its Application to Metal Forming Dies," in Proc. 18th Int. Machine Tool Design and Research Conf., 14-16 Sep 1977, pp. 225-231.

[3] T. Arai, "Carbide Coating Process by Use of Molten Borax Bath in Japan," J. Heat Treat, vol. 18, no. 2, pp. 1522, Dec 1979. [Online] Available: https://doi.org/10.1007/BF02833234

[4] T. Arai, H. Fujita, Y. Sugimoto, et al, "Vanadium Carbonitride Coating by Immersing into Low Temperature Salt Bath," in Heat Treatment and Surface Engineering, George Krauss, Ed., ASM International, 1988, pp. 49-53.

[5] T. Arai, H. Fujita, Y. Sugimoto and Y. Ohta, "Diffusion carbide coatings formed in molten borax systems," $J$ Mater Eng, vol. 9, no. 2, pp. 183-189, Jun 1987. [Online]. Available: https://doi.org/10.1007/BF02833709

[6] H. C. Child, S. A. Plumb, and J. J. McDermott, "Proc. Int. Conf. on Heat Treatment", n. 310, London, UK, The Metals Society, May 1984, pp 5.1.

[7] F.E. Castillejo, D. Marulanda, and J. J. Olaya, (2013, Jul.) "Estudio de recubrimientos de carburos ternarios de niobio-vanadio producidos sobre acero D2 usando la técnica de deposición por difusión Termorreactiva," $R L M M$, vol. 34, no. 2, pp. 1-10, Jun 2014. [Online]. Available: http://www.rlmm.org/ojs/index.php/rlmm/article/view/464

[8] A. Orjuela, R. Rincón, and J. J. Olaya, "Corrosion resistance of niobium carbide coatings produced on AISI 1045 steel via thermo-reactive diffusion deposition," Surf Coat Technol, vol. 259, part C, pp. 667-675, Nov 2014. [Online]. Available: https://doi.org/10.1016/j.surfcoat.2014.10.012

[9] C. K.N. Oliveira, C. L. Benassi, and L.C. Casteletti, "Evaluation of hard coatings obtained on AISI D2 steel by thermo-reactive deposition treatment". Surf Coat Technol 201 pp. 1880-1885. ISSN: 0257-8972. http://www.sinab.unal.edu.co:2053/science/article/pii/S0257897206002787

[10] M. G. Gee, A. Gant, I. Hutchings, R.Bethke, K. Schiffman, K. Van Acker, S. Poulat, Y. Gachon and J. Von Stebut, "Progress towards standardization of ball cratering," Wear, vol. 255, no. 1-6, pp. 1-13, Aug-Sep 2003. [Online]. Available: https://doi.org/10.1016/S0043-1648(03)00091-7

[11] S. Sen. and U. Sen, "Sliding wear behavior of niobium carbide coated AISI 1040 steel," Wear, vol. 264, no. 3-4, pp. 219-225, Feb 2008. [Online]. Available: https://doi.org/10.1016/j.wear.2007.03.006

[12] C. K.N. Oliveira, R. M. Muñoz Riofano and L.C. Casteletti, "Micro-abrasive wear test of niobium carbide layers produced on AISI H13 and M2 steels," Surf Coat Technol, vol 200, no. 16-17, pp. 5140-5144, Apr 2006. [Online]. Available: https://doi.org/10.1016/j.surfcoat.2005.05.037

[13] X.S. Fan, Z. G. Yang, C. Zhang and Y. D. Zhang, "Thermo-reactive deposition processed vanadium carbide coating: growth kinetics model and diffusion mechanism," Surf Coat Technol, vol. 208, pp. 80-86, Sep 2012. [Online]. Available: https://doi.org/10.1016/j.surfcoat.2012.08.010

[14] X.S. Fan, Z. G. Yang, C. Zhang, et al. "Evaluation of vanadium carbide coatings on AISI H13 obtained by thermoreactive deposition/diffusion technique," Surf Coat Technol vol. 205, no. 2, pp. 641-646, Oct 2010. [Online]. Available: https://doi.org/10.1016/j.surfcoat.2010.07.065

[15] S. T. Oyama, "The chemistry of transition metal carbides and nitrides", in Blackie Academic \& Professional, 1996. http://www.books.google.com>... > Chemistry > General.

[16]F. Castillejo, "Recubrimientos de VC y NbC producidos por TRD: tecnología económica, eficiente y ambientalmente limpia," Ciencia Ing Neogranadina, vol 22, no. 1, pp. 95-105, Jun 2012. [Online]. Available: http://www.umng.edu.co/documents/10162/1073246/Articulo_6.pdf

[17] H. Suarez, "Evaluación del comportamiento en condiciones de operación de aceros de baja y media aleación con recubrimiento superficial por el proceso deposición difusión termorreactiva (TRD)," M.S. thesis, Unal, Bogotá, 2003. [Online]. Available: http://www.postmat.unal.edu.co/tesismaestriafinal.html 
[18] J. Mendoza, R. Durán and J. Genescá, “Espectroscopia de impedancia electroquímica en corrosión, en Técnicas electroquímicas para el estudio de la corrosión". [Online]. Available: http://depa.fquim.unam.mx/labcorr/libro/Manual-EIS-IMP-UNAM.PDF

[19] C. Aguzzoli, C. A. Figueroa and F. S. de Souza, A. Spinelli and I.J.R. Baumvol, "Corrosion and nanomechanical properties of vanadium carbide thin film coatings of tool steel". Surf Coat Technol, vol. 206, no. 10, pp. 27252731, Jan 2012. [Online]. Available: https://doi.org/10.1016/j.surfcoat.2011.11.042

[20] A. Guzman, "Evaluación de la resistencia a la corrosión de sistemas de recubrimientos con altos sólidos por medio de espectroscopía de impedancia electroquímica," M.S. Thesis, Fac Minas, Unal, Medellín, 2011. [Online]. Available: http://www.bdigital.unal.edu.co/4063/4/200767791.2011_1.pdf

[21] C. Liu, Q. Bi, A. Leyland and A. Matthews, "An electrochemical impedance spectroscopy study of the corrosion behaviour of PVD coated steels in $0.5 \mathrm{~N} \mathrm{NaCl}$ aqueous solution: Part I. Establishment of equivalent circuits for EIS data modeling," Corrosion Sci., vol. 45, no. 6, pp. 1243-1256, Jun 2003. [Online]. Available: https://doi.org/10.1016/S0010-938X(02)00213-5

[22] S.D. Cramer and B.S. Covino, ASM Handbook, vol.13A Corrosion: Fundamentals, Testing, and Protection, ASM Intern, $2003 \quad$ [Online]. http://www.sinab.unal.edu.co:3021/SUBSCRIPTION/filtrexx40.cgi?REDLINE_PAGES/G192.html

[23] C. Liu, Q. Bi, A. Leyland and A. Matthews, "An electrochemical impedance spectroscopy study of the corrosion behaviour of PVD coated steels in $0.5 \mathrm{~N} \mathrm{NaCl}$ aqueous solution: Part II.: EIS interpretation of corrosion behavior," Corrosion Sci, vol. 45, no. 6, pp. 1257-1273, Jun 2003. [Online]. Available: https://doi.org/10.1016/S0010-938X(02)00214-7

[24]L. Velazco, "Producción, caracterización microestructural y estudio de la resistencia a la corrosión de recubrimientos nanoestructurados de NbxSiyNz depositados con el sistema de UBM," M.S. Thesis, Dpt Ing Mec Mecatronica, Unal, Bogotá, 2011. [Online]. Available: http://www.bdigital.unal.edu.co/4319/

[25] M. Torres, "Estudio comparativo del proceso de corrosión en recubrimientos cerámicos, metálicos y orgánicos mediante técnicas electroquímicas," M.S. Thesis, Dpt. Ing Mec Mecatronica, Unal, Bogotá, 2010. http://www.bdigital.unal.edu.co/3053/

[26] D. Turcio-Ortega, S. E. Rodil and S. Muhl, "Corrosion behavior of amorphous carbon deposit in $0.89 \% \mathrm{NaCl}$ by electrochemical impedance spectroscopy" Diamond and Related Materials, vol. 18, no. 11, pp. 1360-1368, Nov 2009. [Online]. Available: https://doi.org/10.1016/j.diamond.2009.08.013 